\title{
dossier | RESPECT THE GIRLS! \\ discursive analysis on the developments of the chronicle "The Intern/Melissinha's First Day of Work" by Correio Braziliense
}

Copyright (c) 2018 SBPjor / Associação Brasileira de Pesquisadores em Jornalismo

\section{LIZIANE GUAZINA}

University of Brasilia, Brasília - DF, Brazil

ORCID: orcid.org/0000-0002-4765-6918

DIONE OLIVEIRA MOURA

University of Brasília, Brasília - DF, Brazil

ORCID: orcid.org/0000-0003-2857-3284

\section{FABÍOLA CALAZANS}

University of Brasília, Brasília - DF, Brazil

ORCID: orcid.org/0000-0002-7455-5936

FERNANDA MARTINELLI

University of Brasília, Brasília - DF, Brazil

ORCID: orcid.org/0000-0002-0196-048X

\section{LILIANE MACHADO}

University of Brasilia, Brasília - DF, Brazil

ORCID: orcid.org/0000-0002-0196-048X

DOI: https://doi.org/10.25200/BJR.v14n1.2018.1067

\begin{abstract}
In this article, our objective is to discuss the production of gender inequality by journalism, both in the content production and in media companies' work structures, and the public process of denouncing this phenomenon in social networks. The publication of a chronicle in the newspaper Correio Braziliense entitled "The Intern/Melissinha's first day of work", is the starting point. By sexualizing the entry of young women journalism students into the newspaper's editorial office, the chronicle reproduces and naturalizes gender-based violence that is systematically installed in some of these spaces. We note that the case can be understood as a feminization process that undertook discursive battles to combat gender discrimination against female journalism interns or against professional journalist women.
\end{abstract}

Key words: Journalism. Genre. Feminization. Discursive formations. Correio Braziliense. 


\section{RESPEITA AS MINA! Análise discursiva sobre os desdobramentos da crônica "A estagiária/O primeiro dia de Melissinha", do Correio Braziliense}

RESUMO - Neste artigo, nosso objetivo é discutir a produção da desigualdade de gênero pelo jornalismo, tanto na produção de conteúdo quanto nas estruturas de trabalho das empresas de mídia, e o processo público de denúncia deste fenômeno nas redes sociais. A publicação de uma crônica no jornal Correio Braziliense intitulada "A Estagiária/O primeiro dia de trabalho de Melissinha", é o ponto de partida. Ao sexualizar o ingresso de jovens mulheres estudantes de jornalismo na redação do jornal, a crônica reproduz e naturaliza violências de gênero que se instalam de forma sistemática em alguns desses espaços. Observamos que o caso pode ser compreendido como um processo de feminização que empreendeu batalhas discursivas de combate à discriminação de gênero contra estagiárias de jornalismo ou contra mulheres jornalistas profissionais.

Palavras-chave: Jornalismo. Gênero. Feminização. Formações discursivas. Correio Braziliense.

\section{¡RESPETA LAS CHICAS! Análisis discursivo sobre los desdoblamientos de la crónica "La interna / El primer día de Melissinha", del Correo Braziliense}

RESUMEN - En este artículo, nuestro objetivo es discutir la producción de desigualdad de género por el periodismo, tanto en la producción de contenido, como en las estructuras de trabajo en las empresas mediáticas y el proceso público de denuncia de este fenómeno en las redes sociales. La publicación de una crónica en el periódico Correio Braziliense intitulada "La pasante/El primer día de trabajo de Melissinha", es el punto de partida. Con la sexualización del ingreso de jóvenes mujeres estudiantes de periodismo en la redacción de un periódico, la crónica reproduce y naturaliza violencias de género que se instalan de forma sistemática en algunos de esos espacios. Observamos que el caso puede ser entendido como un proceso de feminización que emprendió batallas discursivas contra la discriminación de género contra las pasantes de periodismo y periodistas profesionales.

Palabras-Clave: Periodismo. Género. Feminización. Formaciones discursivas. Correio Braziliense.

\section{Introduction}

This is a study about the production of gender inequality in Brazilian journalism from the relationship between content production and the media companies internal structures, and how the confrontation of this inequality occurs through discursive battles undertaken in social networks. The publication on September 11 , 2017 of a chronicle in the newspaper Correio Braziliense (CB) entitled "The Intern/Melissinha's first day of work", as well as its unfolding, is the starting point. The text describes what would be the first day 
of work of a female journalism intern', and does so in a sexualized manner, endorsing gender violence, which led to public criticism by feminist groups and trade unions to the content of the text.

Correio Braziliense is still the main newspaper of Brasilia, the federal capital, founded along with the city in 1960. According to data from the National Association of Newspapers (ANJ, 2015), CB took the tenth national position in terms of digital circulation and the twentieth position among Brazilian newspapers with the largest national circulation. Although strongly linked to the reality of the Federal District, it is a reference newspaper that usually covers the main national issues, especially those related to national politics.

Before joining the analysis of the chronicle and its public repercussions, we retrieve some data that provide a basis to think about journalistic practices and make the connection between the more specific context of the object and the broader panorama of changes in the sexual division of labor in journalism.

The increasing presence of women in the world of journalism, as well as the change in professional practices resulting from this factor, has been a process registered in some countries markedly since the mid-twentieth century. This increasing number of women in a professional field, according to Yannoulas (2011), can be observed from two dimensions: feminilization, understood as a quantitative increase of women in a profession, and feminization, which can be defined as a process in which transformations in the professional practice due to the greater presence of women in a certain professional field are perceived.

In the international scenario, the report Global Report on the status of women in the news media, published by the International Women's Media Foundation (Byerly, 2011), shows that only 33.3\% of the 522 companies surveyed had women journalists working full time. This report, as well as its subsequent edition, also with a global mapping, Byerly (2013) prove that there is much to be achieved in terms of fairness in the professional journalism market for women journalists on all continents, with major or minor advances, according to geopolitical scenarios and regions.

Brazil presents a particular reality in relation to the majority of the nations surveyed by the International Women's Media Foundation (Byerly, 2011), aforementioned: since, in the Brazilian case, at least since the second decade of the XXI century, studies such as the Syndicate of Professional Journalists of the Federal District (2016) and 
Jacks and Mick (2013) indicate, there has been an effective increase of women journalists in Brazil. However, this phenomenon does not represent an increase in women journalists in positions of decisionmaking power (managers, editors, directors, etc.) nor an equal proportion of women in higher salaries (Koshiyama, 2001; Martinez, Lago \& Lago, 2016; Mick \& Lima, 2013; Ramos, 2010; Rocha, 2004; Rocha et al., 2013; Rocha and Sousa, 2011 ; Rocha \& Woitowicz, 2017; Silva, 2014; Souza, 2009).

The increase of women in professional journalism practice, in the Brazilian case, dates back to the second half of the twentieth century, having obtained the greatest rise from the 1960s onwards, with increasing journalism degree courses (Rocha, 2004) ${ }^{2}$. In 1986, women accounted for about 35\% of the journalism professionals, and in 2005 , this percentage rose to more than $50 \%$ of professionals, according to Rocha and Sousa (2008). In the first decade of the $21^{\text {st }}$ century, Mick and Lima's national survey (2013), conducted by the Postgraduate Program in Political Sociology of the Federal University of Santa Catarina (UFSC), with the support of the National Federation of Journalists (Fenaj) and the Brazilian Association of Journalism Researchers (SBPJor), recorded that $64 \%$ of Brazilian journalists are women (data collected in the year 2012).

This scenario which contrasts the increase in the number of women in journalism (feminilization) and the paradox that women journalists have not achieved gender equality at the command posts, as well as the persistence of a wage inequality, is not an exclusively Brazilian phenomenon though, as pointed out by Gudipaty et al (2018), from a broad comparative perspective in the context of the BRICS and, as documented by comparative studies in several continents, such as those organized by Byerly $(2011,2013)$.

In the closer context of our case study, in 2016, the Collective of Women Journalists of the Syndicate of Journalists of the Federal District (SJPDF) carried out the survey "Gender Inequality in Journalism". Respondents reported cases of harassment (77.9\% reported having been harassed by their boss or colleague), machismo practice $(78.5 \%$ stated that some interviewees had a macho attitude during interviews), among other forms of violence in the exercise of the professional practice. The Syndicate's survey (2016) heard journalists from several states, and other studies also prove that the practice of sexual and/or moral harassment against women journalists is a national reality (Carvalho \& Portella, 2016; Souza \& Bueno, 2017). 
In view of the gender inequalities mentioned, it is necessary to ask: how do women develop practices of mobilization and coping around the issues of harassment (moral or sexual) and discrimination in the exercise of professional practice? The case of the publication of the chronicle "The Intern/Melissinha's first day of work" by the newspaper Correio Braziliense provides us with clues about the paths taken by groups and class entities in the mobilization of discursive battles that face the sexism observed in the texts and in the journalistic work environment. Such discursive battles must be understood, as we shall see later, from a socio-historical look relating " individual practices to their social and historical conditions of possibility and unfoldment, to their space of the possible and conceivable 3 (Buton, 2009). They are contexts, therefore, that signal the materiality of the process of feminization of journalism in the country.

In the analysis that follows, we observe that the process of feminization, although slow, is materialized in the social reaction of social actors (Syndicate of Professional Journalists of the Federal District, National Federation of Journalists and Collective Journalists against Harassment), but not only these institutions and collectives - through the identification, denunciation, judicialization and institutional and/or collective action against the practices of harassment and discrimination of women in the exercise of journalism, as well as in the modeling of new professional practices, as recorded by Del Vecchio-Lima and Souza (2017). These campaigns include, among other strategies, discursive battles with the production of public letters, identification booklets for the prevention of harassment and discrimination against female journalists or female journalism interns, and the promotion of workshops, seminars and events with the same topic in journalistic companies via independent union and/ or collective associations and institutions of higher education.

\section{The chronicle}

As Maingueneau (2002, p. 61) well defines, "there is no discourse other than contextualized", and the scenario described above is the one of contextualization of the discursive battles fought in the process of feminization of Brazilian journalism. In the present case study, we analyze the results of the publication of the chronicle "'The Intern'/Melissinha's first day of work" (Goulart, 
2017a), published in the newspaper and in the Correio Braziliense (CB) website, on September 11, 2017. Our objective is to discuss the production of gender inequality by journalism and the public process of denouncing this phenomenon in social networks based on the example of Correio Braziliense.

In the chronicle, editor Guilherme Goulart narrates the first day of work of the new female intern and describes the "character", with details, emphasizing her physical attributes:

Naughty cleavage, bare thighs, little feet sweetly tucked into
little sandals. As if she were on a catwalk, the 19-year-old girl
- freshly turned - paraded through the newsroom, swinging her
hips, back and forth, back and forth. She hid the nervousness
with the walking as light and bright as a feather. (Goulart, 2017a).

At the same time, he describes his newsroom colleagues as "male wildlife," "pack" and "machos," "desperate," and naturalizes their reactions of explicit sexual interest and harassment toward the student. After the publication of the chronicle in the Correio Braziliense (CB) portal, which was removed from the air hours later, the newspaper published a retraction of the author entitled "An error without forgiveness", on September 12 $2^{\text {th }}, 2017$ (Goulart, 2017b), where it says the character was created "to show that the problem of harassment of women continues to be a frightening reality."

CB's next edition, dated September $13^{\text {th }}, 2017$, presented a text signed by the editor-in-chief, Ana Dubeux, titled "Time to Change" (Dubeux, 2017). In it, she says the published chronicle "is out of alignment" with the newspaper's mission and "out of what we believe is our role in society with our readers." In the text, the editor-in-chief reveals that, before being published, the journal had been read by two journalists - a man and a woman - and that none had attempted to "content gravity", what would show, according to her, the naturalization of machismo in daily life. On the same date, CB published the repudiation notes of the National Federation of Journalists (Fenaj) and the Syndicate of Professional Journalists of the Federal District (SJPDF), both strongly criticizing the content of the chronicle. Between September $12^{\text {th }}$ and 15 th 2017,12 portals and/or sites published news, commentaries or notes on the topic. Precisely these developments are the focus of our observations made through Discursive Formations present in social networks as well as praxis that erupted after the publication of the chronicle. 


\section{Methodological path}

In a first moment, a data survey was carried out taking into account the period from September 11 to 18,2017, a week defined from the first day of publication of the chronicle "'The Intern'/Melissinha's first day of work" in CB, and corresponded to the collection of publications, comments, likes, shares and reactions on the subject of the profiles of the Syndicate of Journalists of the Federal District (SPJDF), Journalists against Harassment, National Federation of Journalists (Fenaj) and Correio Braziliense (CB) on social networks Facebook and Twitter. The constitution of this corpus was done through direct data collection with the purpose of initially quantifying the occurrences of publications, comments and reactions and identify if there was hashtag on the subject $^{4}$. In a second step, these selected data were analyzed through the French Discourse Analysis and the notion of discursive formations in order to map the most frequent meanings present in the postings and interactions, as well as the discursive silencing.

We observed that in the analyzed week there were publications, comments, likes, shares and reactions related to the chronicle in the selected profiles only on days 11, 12 and 13 of September, 2017, so that, between September $14^{\text {th }}$ and $18^{\text {th }}, 2017$, there were no identified occurrences of the topic in the agenda of the social networks of the analyzed profiles. On Facebook as well as on Twitter, it was possible to identify a higher frequency of publications and interactions located in the profile of the Collective Journalists against Harassment (@ jornasxassedio) and this was, in particular, the one that most stimulated the debate about the chronicle. There were two publications on Facebook (one on $11^{\text {th }}$ and another one on the $12^{\text {th }}$ ) which together had 1,282 comments, 5,378 reactions and 2,280 shares. On Twitter, the same Collective held 14 posts that obtained 54 retweets and 61 likes in the same period. The Syndicate of Journalists of the DF also made two publications on the subject on Facebook, one on the $12^{\text {th }}$ and another on the $13^{\text {th }}$. Together, they both had 62 comments, 319 reactions and 106 shares. On Twitter, two posts were made on those same days, and these received only 2 retweets and 3 likes. Correio Braziliense did not publish on the subject in the week analyzed in either of the two social networks, although it had a commentary on the topic on Facebook, and the National Federation of Journalists made a publication on Facebook on the $11^{\text {th }}$, with four comments, 63 reactions and 63 shares. The summarized survey above is available in Tables 1 and 2. 
Table 1- Quantitative of the actions and reactions generated in the analyzed profiles of Facebook and referring to the chronicle "The Intern/Melissinha's first day of work"

\begin{tabular}{|c|c|c|c|c|}
\hline $\begin{array}{l}\text { ANALYZED } \\
\text { PROFILES }\end{array}$ & $\begin{array}{c}\text { SYNDICATE } \\
\text { OF } \\
\text { JOURNALISTS } \\
\text { (DF) }\end{array}$ & $\begin{array}{c}\text { CORREIO } \\
\text { BRAZILIENSE }\end{array}$ & $\begin{array}{l}\text { JOURNALISTS } \\
\text { AGAINST } \\
\text { HARASSMENT }\end{array}$ & $\begin{array}{c}\text { NATIONAL } \\
\text { FEDERATION } \\
\text { OF } \\
\text { JOURNALISTS }\end{array}$ \\
\hline \multicolumn{5}{|l|}{$9 / 11 / 2017$} \\
\hline $\begin{array}{l}\text { Publications } \\
\text { on the subject }\end{array}$ & 0 & 0 & 1 & 1 \\
\hline $\begin{array}{l}\text { Comments on } \\
\text { the post }\end{array}$ & 0 & 1 & 1.238 & 4 \\
\hline $\begin{array}{l}\text { Reactions in } \\
\text { the post }\end{array}$ & 0 & 0 & 5.100 & 63 \\
\hline Post Shares & 0 & 0 & 2.234 & 63 \\
\hline \multicolumn{5}{|l|}{$9 / 12 / 2017$} \\
\hline $\begin{array}{l}\text { Publications } \\
\text { on the subject }\end{array}$ & 1 & 0 & 1 & 0 \\
\hline $\begin{array}{l}\text { Comments on } \\
\text { the post }\end{array}$ & 50 & 0 & 44 & 0 \\
\hline $\begin{array}{l}\text { Reactions in } \\
\text { the post }\end{array}$ & 232 & 0 & 278 & 0 \\
\hline Post Shares & 86 & 0 & 46 & 0 \\
\hline \multicolumn{5}{|l|}{$9 / 13 / 2017$} \\
\hline $\begin{array}{l}\text { Publications } \\
\text { on the subject }\end{array}$ & 1 & 0 & 0 & 0 \\
\hline $\begin{array}{l}\text { Comments on } \\
\text { the post }\end{array}$ & 12 & 0 & 0 & 0 \\
\hline $\begin{array}{l}\text { Reactions in } \\
\text { the post }\end{array}$ & 87 & 0 & 0 & 0 \\
\hline Post Shares & 20 & 0 & 0 & 0 \\
\hline TOTAL & 489 & 1 & 8.942 & 131 \\
\hline
\end{tabular}

Source: Data obtained on Facebook and table prepared by the authors

Note: From September $14^{\text {th }}$ to $18^{\text {th }}, 2017$ all fields of all profiles are equal to zero. 
Table 2 - Quantitative of the actions and reactions generated in the analyzed profiles of Twitter and referring to the chronicle "The Intern/Melissinha's first day of work"

\begin{tabular}{|c|c|c|c|c|}
\hline $\begin{array}{l}\text { ANALYZED } \\
\text { PROFILES }\end{array}$ & $\begin{array}{l}\text { SYNDICATE OF } \\
\text { JOURNALISTS } \\
\text { (DF) }\end{array}$ & $\begin{array}{c}\text { CORREIO } \\
\text { BRAZILIENSE }\end{array}$ & $\begin{array}{l}\text { JORNALISTS } \\
\text { AGAINST } \\
\text { HARASSMENT }\end{array}$ & $\begin{array}{c}\text { NATIONAL } \\
\text { FEDERATION } \\
\text { OF } \\
\text { JORNALISTS }\end{array}$ \\
\hline \multicolumn{5}{|l|}{$9 / 11 / 2017$} \\
\hline $\begin{array}{l}\text { Tweets on } \\
\text { the subject }\end{array}$ & 0 & - & 7 & - \\
\hline $\begin{array}{l}\text { Retweets in } \\
\text { the post }\end{array}$ & 0 & - & 44 & - \\
\hline Post Likes & 0 & - & 42 & - \\
\hline \multicolumn{5}{|l|}{$9 / 12 / 2017$} \\
\hline $\begin{array}{l}\text { Tweets on } \\
\text { the subject }\end{array}$ & 1 & - & 7 & - \\
\hline $\begin{array}{l}\text { Retweets in } \\
\text { the post }\end{array}$ & 2 & - & 10 & - \\
\hline Post Likes & 3 & - & 19 & - \\
\hline \multicolumn{5}{|l|}{$9 / 13 / 2017$} \\
\hline $\begin{array}{l}\text { Tweets on } \\
\text { the subject }\end{array}$ & 1 & - & 0 & \\
\hline $\begin{array}{l}\text { Retweets in } \\
\text { the post }\end{array}$ & 0 & - & 0 & \\
\hline Post Likes & 0 & - & 0 & \\
\hline TOTAL & 7 & - & 129 & \\
\hline
\end{tabular}

Source: Data obtained on Facebook and table prepared by the authors.

Note: The @correio Twitter profile publications were unavailable for viewing during the data collection phase; FENAJ Twitter has not been updated since 2013; From September $14^{\text {th }}$ to $18^{\text {th }}, 2017$ all fields of all profiles are equal to zero.

In the period initially delimited for analysis, there was no recurring use of an exclusive hashtag, although this happened later. Even though apparently the debate on the chronicle has cooled from September $14^{\text {th }}$ to $18^{\text {th }}, 2017$, the subject of harassment in journalism 
returned potent on September $26^{\text {th }}, 2017$, occasion of the launching of the campaign \#TogetherAgainstMachismo by the Collective Journalists against Harassment. The action of this campaign was central to the analysis of one of the discursive formations observed in the discussions that followed on the chronicle, the Confrontation Strategies Discursive Formation, presented as follows.

\section{The Discursive Formations}

The notion of discursive formation, according to Maingueneau, "designates every system of rules that founds the unity of a set of socio-historically circumscribed utterances" $(2002,68)$. This is a fundamental notion for the French Discourse Analysis (AD), which associates textual organization with the communication situation in which discourses are formulated. As Maingueneau further observes (1997, pp. 13-14):

\footnotetext{
AD crucially relies on the concepts and methods of linguistics, but this is not, evidently, a very discriminating trait. In fact, other dimensions need to be taken into account; AD relates to texts produced: - in the framework of institutions that strongly restrict enunciation; - in which historic conflicts are crystallized, etc.; - that delimit an own space outside the inter discourse.
}

In this way, as we opt for the French AD, we make it aware of the triple inheritance of this theoretical field - coming from linguistics, historical materialism and psychoanalysis - as Ferreira (2010, p. 1) states. "It is precisely in the discourse that the issues related to language, history and the subject are concentrated, overlapped and confused as a true knot". The French AD demarcates, continues the author, a linguistic materiality and, at the same time, a historical materiality, to the discursive object. Orlandi (2003, p.2) adds that the methodology "has developed consciously maintaining certain principles on the relation language/subject/history [...], having the discourse as place of observation of this relation".

And in our research, observing the outbreak of public debate in social networks, from the chronicle "'The Intern'/ Melissinha's first day of work"we realized that the French AD would be a suitable method exactly for the possibility of observing both the linguistic materiality (manifested in the CB chronicle, in 
the letters and posts of the entities SJPDF and Fenaj, in the CB editor's letter, in the posts and campaign of the Journalists Against Harassment Collective) as well as historical (manifest) materiality and, finally, the subject (female journalists in action in the process of feminization of journalism).

There is, therefore, a set of sociohistorical injunctions that enable the enunciation of discursive formations that can be analyzed in the set of discussions publicly undertaken by different social actors in multiple loci of debate. Given the diversity of actors involved and the space we have for the elaboration of this article, we opted to favor the analysis of three discursive formations observed during the week that constituted our corpus of analysis. We emphasize that this option took into account the positioning set of the main subjects involved in the debate about the chronicle (the newspaper in its printed and online versions and the publications in the social networks of entities and collectives) from the mobilization movements of the respective discourses to which they resorted in the discursive battle that was established after the publication of the chronicle.

Thus, it was possible to identify the a) Silencing Discursive Formation, in which the silence of Correio Braziliense in the social networks is perceived, after the publication of the chronicle; the $b$ ) Denunciation Discursive Formation, in which the denunciation of the trade union associations (Fenaj and SJPDF) and of the Collective of Journalists against Harassment is observed, that the chronicle constitutes a situation of sexual harassment and that, in the face of such a practice, would be necessary to use gender solidarity and institutional actions to prevent and combat harassment and discrimination, and finally, the c) Confrontation Strategies Discursive Formation, which identifies the adoption of strategies by journalists in facing harassment and discrimination in the daily life of the profession. In the following, we will describe the main characteristics of each discursive formation.

\section{The Silencing Discursive Formation: the silence of those who are not innocent}

After a preliminary analysis of the corpus, we verified the first discursive formation, which we call Silencing Discursive Formation, 
marked by the not-said about the chronicle on the part of Correio Braziliense in its social media, Facebook, Twitter and Instagram. If the chronicle was posted on one of these media, it was probably taken off the air. During the analyzed period, from September $11^{\text {th }}$ to $18^{\text {th }}$, 2017, there were 121 Correio Braziliense publications on Facebook and 118 on Instagram, yet none of them referred to the subject in question. It is worth mentioning that this period was unavailable for Twitter search of the Correio Braziliense profile, even on different platforms, devices and browsers.

Silencing can be understood as a way of being in language; the importance of observing what the meanings of silence are. Orlandi (2007, p.12) notes that "silence has been relegated to a secondary position as an excrescence, like the rest of language. Our work erects it into an essential factor as a condition of meaning". Therefore, the following questions arise: why has the newspaper opted for this attitude? Would not it be better to face the crisis that settled after the negative repercussion about the chronicle? It is important to remember that in the printed edition of CB, on September $13^{\text {th }}, 2017$, the attitude was opposite, since several notes were sent by union entities contrary to the chronicle - manifestations of the Denunciation Discursive Formation -, besides the editorial written by the editorin-chief, as mentioned earlier, in which she states: "As chief editor, I take responsibility for the changing process in the newspaper. We will promote conduct policies, discussion tables and, above all, we will invest in the creation of a collective learning environment "(Dubeux, 2017, p.10).

No doubt, it is contradictory for the company to state something in the printed version, see letter mentioned above, and forget everything on the other platforms it covers. As Orlandi (2007, p.24) says about silence, he is "the possibility for the subject to work out its constitutional contradiction, which places it in the relation of the 'one' to the 'multiple."

However, some readers were keen to mention the case. This can be seen not only in Internet users' comments, but also in the public notices by SJPDF and Fenaj entities, which demarcate a character of indignation and a desire for a practical attitude on the part of CB. In three comments from Internet users published on September $11^{\text {th }}, 2017$, one on Facebook and two on Instagram, for example, one can perceived the reactions of the public. An Internet user comments on Correio Braziliense's Facebook not believing 
that "that misogyny chronic comparing its interns with something to be consumed by the macho colleagues" was published by the newspaper. The other two comments from Instagram demand a position by Correio Braziliense about the chronicle: "And that chronicle? Will CB not position itself? Bad!!!" and "Waiting for the position of @correiobraziliense on the Chronicle of “Melissinha”. These comments mark a character of indignation and desire for a practical attitude on the part of the Brazilian newspaper. As Orlandi (2007) observes, there is a political dimension in the silence that allows us to observe the rhetoric of domination and oppression. In the analyzed case, one clearly perceives, as Orlandi (2007) points out, that silence is the real of the discourse. For the purpose of this work, what matters are the analysis of the discursive materiality of the corpus in question, which leaves no doubt the option of the immediate and embarrassing silence that the vehicle assumed before the netizens. It is important to emphasize that this Silencing Discursive Formation was publicly criticized, that is, it was inserted in a discursive battle: netizens, especially in the social networks of the Collective Journalists against Harassment and also the SJPDF and Fenaj entities.

\section{The Denunciation Discursive Formation: union entities point to gender solidarity}

The second discursive formation, which we call Denunciation Discursive Formation, refers to the forceful way in which SJPDF and Fenaj union associations, as well as the Collective Journalists against Harassment, stood before the chronicle "The Intern/Melissinha's first day of work", denouncing it as one of several forms of women harassment in news vehicle newsrooms. During the analyzed week, in the Journalists' Union profile, there were 2 publications on the chronicle, as indicated in Tables 1 and 2. The SJPDF's public note had an effect, as it was published in $C B$ the following day and it also unfolded in various SJPDF and $C B$ workshops and events on harassment against women journalists or journalism interns' prevention and combat.

Let us look at the following image in Figure 1 so that we can evaluate the general composition of the posts. 
Figure 1: Posts of the Journalists of the Federal District Syndicate (SJDF) profile, on September 12 and 13, 2017.

\section{(image on the left)}

"The Syndicate of Professional Journalists of DF and the Collective of Women Journalists of the DF repudiate the text and ask the newspaper's management to explain the publication of the content, which is not only the journalist's responsibility but, above all, the responsibility of the vehicle. In addition, they are in solidarity with the female journalists and interns who are directly affected and with all the others who have already been victims of harassment. "Read the full article https://goo.gl/8f7XFP

\section{(image on the right)}

The newspaper positioned itself after the negative repercussion in the social networks and of the collections of the Union of Journalists of the DF and of the National Federation of Journalists. In addition to the apologies, Ana Dubeux, the newspaper's chief editor, says the vehicle will undergo changes and promote policies of conduct, discussion tables and investing in a collective learning environment. Check out! http://bit.ly/2h4q1k9

Sindicato Dos Jornalistas

22 de setembero is $11: 38$ - $\mathrm{e}$

"O Sindicato dos Jornalistas Profissionais do DF e o Coletivo de Mulheres Jornalistas do DF repudiam o texto e pedem explicaç̃es a direçђo do jornal sobre a publicaçło do conteúdo, de responsabilidade năo somente do jornalista, mas, sobretudo, do veículo. Além disso, se solidarizam com as jornalistas e estagiárias frontalmente atingidas $e$ com todas as outras que já foram vitimas de assédio". Confira a nota completa https://goo.gl/8r7XFP

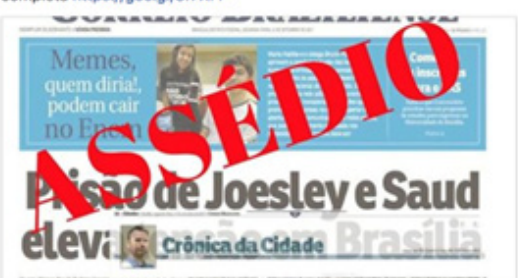

Sindicato dos Jornalistas do DF publica nota em repúdio ao texto "A estagiária" do jornal Correio Braziliense S.JPDF

DC Curtir $\square$ Comentar $\phi$ Compartilhar
020232
88 compartihnamentos

Sindicato Dos Jornalistas

jornal se posicionou depois da repercusslo negativa nas redes sociais e das cobranceas do Sindicato dos Jornalistas do DF e da Federacto Nacional des Jornalistas. Para além das desculpas, Ana Dubeux edihora-chete do lornal, afirma que o velculo passar, Ana

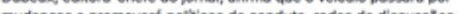
mudanças e promover polticas de conduta, rodas de discusscles investir em ambiente de aprendizado coletivo. Confira! http://oit.ly/2h4a1k9

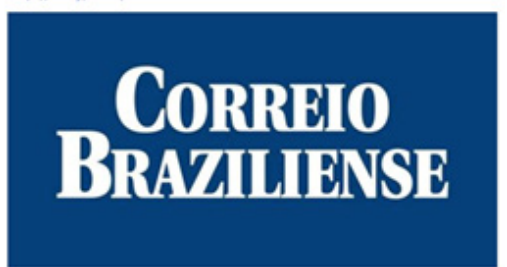

Retratação: Correio Braziliense pede desculpas pela publicaçio do texto "A Estagiária" - SJPDF

Sou jornalista, mse, ande, desde 2003, eshorb-chefe do Correio Braziliense. Nonto hivibria grefision suorono:be

¿Curtir $\bigcirc$ comentar $\&$ compartilhar

OO Lucas de Mones e ouras 86 pesscas

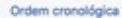

20 comeartinumentos

Source: https://www.facebook.com/SJPDF. Accessed on: 14 Sep 2018. 
The image to the left of Figure 1 carries the word "harassment" arranged in red color, in a capital letters and skewed on the image of the newspaper, just like a stamp indicating a crime. The notion of repudiation and denunciation stands out. The problem is faced, since it is exposed and visualized in a forceful way. The newspaper, in turn, is questioned, since part of the text asks for explanations to the newspaper, besides affirming that the publication is not only responsibility of the journalist, but, "mainly, of the vehicle". In fact, even in the case of the chronic genre, which according to Pena (2007), circumscribes along with others - such as editorial and column - the idea of opinionated journalism, which allows professionals to weave their opinions about the facts, the chronicle in question was read before the publication, as admits the editor-in-chief (Dubeux, 2017).

The end of the Syndicate's text, described above, uses gender solidarity to female journalists or interns who have already been victims of harassment. As Maingueneau (2002, p. 62) states, "discourse only makes sense within the universe of other discourses ...". Therefore, to interpret the discourse, we have to relate them to other discourses, concludes the author. In this sense, when the text of the SJPDF makes use of gender solidarity, we see that this position is connected to the inter discourse of the struggle undertaken by the feminist movements, which proclaim the need for women to practice sorority, which can be implemented through complaints about violence suffered by women in various places, as well as the need for them to embrace such a cause, regardless of whether they belong to the same profession, race or sexual orientation.

Although Machado (2017, p.117) points out how the idea of sorority remains a taboo in contemporary Western societies: "What does common sense offer as narrative possibilities about friendship between women? In general, scorn, mockery, disbelief", we, nevertheless, observe a contrary meaning to the resistance to sorority mentioned by Machado, since, in our analysis, the Union is inserted in the inter discourse of feminist struggles

The second image, to the right of Figure 1 , refers to the retraction and apology made by $C B$ regarding the chronicle, as well as the letter from the editor-in-chief (Dubeux, 2017), about which we referred earlier. At the end of the text, the apology appears with the promise of change, as it can be seen in the following passage 
from Dubeux: "I apologize to all women, readers, employees, former employees and also to men who have felt uncomfortable during the reading. This unacceptable event will be a milestone for a deeper change" (Dubeux, 2017). The position of CB travels between the Silencing Discursive Formation, through the silencing of the newspaper in the social networks, and the Confrontation Strategies Discursive Formation, position for which $C B$ was called, amidst the discursive battles triggered by SJPDF, Fenaj and the Collective Journalists Against Harassment; this action has resulted in workshops and seminars held jointly by SJPDF and CB, in the period after the unfolding of the chronicle in question.

Fenaj, in turn, used the social network Facebook to disclose the repudiation note that it wrote and that was published on September $13^{\text {th }}, 2017$. We counted four comments on the subject. Although the theme has had repercussions among journalists, especially those who work in Brasilia, there has been little engagement in the social networks of the Federation, with only 63 shares. However, it is undeniable the importance of the tone of repudiation used by Fenaj, since it denounces the chronicle as "misogynistic and revealing of how the different forms of violence against women journalists and students of Journalism occur in the exercise of their professional activities [...]". The Fenaj note also came to be published in CB, in the same way as the SJPDF one, both in the fight against sexual harassment against female journalists and journalism interns.

Once again, we observe in the corpus the inter discourse between the notes produced by SJPDF and Fenaj with the feminist movements. According to the definition proposed by Arruda (2000, p. 127): "the feminist theory, starting from a political project, intends to go beyond the mere understanding of the phenomena of oppression and subordination. Understanding them becomes a medium activity for the goal of transforming relations between genders"; which are movement flags, especially those located in the third feminist wave $^{5}$. According to Maingueneau (1997, p. 120), "interdiscursivity is constitutive, that is, a discourse does not arise from some return to one's own things [...] but from a work on other discourses". In this way, we perceive that SPJDF and Fenaj echo the interdiscursivity of feminist proposals, accepting them and divulging them in the discursive practices around the present case study. 


\section{Between denunciation and confrontation: Journalists against harassment}

The relevant engagement of the journalists' class on the subject of harassment in the newsrooms moved it more endogenously, circumscribed to small groups, than exogenous and of social mobilization. Among these groups, the one that was the most outstanding was the Journalists against Harassment Collective with 2 publications during the analyzed period, which generated a large number of engagements - comments/shares/likes, as the quantitative mentioned earlier in this article demonstrates. It is noteworthy that the profile analyzed was not the closed group, but the public page of the group, so that the arranged images are free to view.

The Collective Journalists Against Harassment appeared in 2016, in solidarity with a journalist of the portal iG who was fired after reporting that she had suffered sexual harassment by singer Biel. At the time, the following comment was posted: "[...] she (the fired journalist of $\mathrm{iG}$ ) is not the only one: there are dozens of routine reports that cannot be naturalized nor thrown into oblivion," published in Journalists Against Harassment portal. The Collective also qualified as a recurrent, the harassment suffered by women in the newsrooms and broadcasters in the country, and is presented as follows:

who - women journalists

what - are still harassed

where - in professional activity

when - more often than you might think ...

The assertive positioning of the Collective can be observed again on the day of publication of the chronicle by $C B$ as it can be verified in the text set forth below:

To the female fellow journalists of Correio Braziliense, our solidarity. It is emblematic that such a perversity is published by an editor in one of the most traditional periodicals in Brasília - a city where harassment is still so present in relations with sources. It is also emblematic that one of the first researches on harassment in Brazilian newsrooms was conducted by the Syndicate of Journalists of the Federal District (read here: https://goo.gl/yKusJm) - according to which almost $80 \%$ of journalists suffer moral harassment in the work environment. By this way, and the writing of the Post seems to exemplify this, the field to be researched is very broad. \# JournalistsAgainstHarassment to be assigned because they are women. 
Collective's posts also point to the interdiscursivity that is established with the feminist movements. Among the most relevant, we highlight the complaint about the macho attitude that prevails in informative vehicles newsrooms. Machismo is the popularly used version of patriarchal societies characterized by the naturalization of prevailing social relations, such as the notion of compulsory heterosexuality, the division of functions for men and women, and women are given the ideal of motherhood and care of the other, and to men the public space of intellect, reason. It should be emphasized that such social arrangements are intended to justify the assertion about the inferiority of women to men, an inferiority that would justify wage and political asymmetries, etc.

The inter discourse with feminist theories and movements proceeds when the post of the Collective states that CB must take responsibility for publishing material that naturalizes the violence of which women are victims. Here again we find an element of interdiscursivity between the Strategy Discursive Formation, via Collective, and the critique of naturalization of violence, since "naturalization" is a founding notion in feminist theories, in unmasking the assertion that the woman's social condition is the fruit of women's biology.

\section{The Confrontation Strategies Discursive Formation: combating harassment and discrimination against women}

Finally, Confrontation Strategies Discursive Formation. In this discursive formation, it is notorious that syndicate entities as well as collective ones created in the social networks are attentive to the discursive practices formulated in the news vehicles, denouncing situations of oppression, pointing to needs of immediate changes and calling the editors and journalists' responsibility for a coherent conduct to the rights of the press professionals. In this sense, there are several efforts of women and men journalists in solidarity with the institutional actions of prevention and coping with harassment. In particular, the online campaign "\#TogetherAgainstMachismo" was a direct response, according to the Collective itself, to the chronicle in question, which also mobilized male journalists. Starting on September $26^{\text {th }}, 2017$, the objective of this campaign organized by the Journalists Against Harassment profile was to show that "the fight against harassment is, first and foremost, a struggle against 
machismo", according to the hashtag (Cf. https://www.facebook. com/jornalistascontraoassedio/ The first action consisted of a tweet with the following call arranged in the event post titled "Twitter \#TogetherAgainstMachismo":

\author{
Sisters, \\ tomorrow we launch a new campaign by the collective Journalists \\ Against Harassment: the \#TogetherAgainstMachismo. \\ Since the beginning, with the phrases reporting situations \\ of harassment still present in the daily life of the profession, \\ you were fundamental. Now, we have all the help to carry the \\ message of the project ahead (tomorrow we will announce \\ it in our fan page) and for TWITTER that begins at 10:00 am \\ - we will retweet and share our profile, www.twitter.com/ \\ jornasxassedio. \\ What it takes: a phrase that expresses machismo still \\ to be fought in the profession, followed by the hashtag \\ \#TogetherAgainstMachismo. \\ Example (taken from what you have sent): \\ "I like to work with you because you work like a man." Until \\ when? \#TogetherAgainstMachismo " \\ OR \\ a comment about the campaign, plus the hashtag.
}

Come with us?! The campaign is beautiful!

The campaign lasted 12 days, from September $26^{\text {th }}$, 2017, and published six videos with testimonials from male journalists commenting on typical habitual harassment phrases in the professional journalistic environment. In the first campaign video, it is possible to notice that one of the main motivations for this action was the publication of the chronicle "'The Intern'/ Melissinha's first day of work", because, in the introduction, there were published several sections completely extracted from the text published in Correio Braziliense, as well as the image of the CB chronicle.

Based on reflections on the stalking phrases spoken in the ordinary environment of journalists, the campaign of the Collective Together Against Harassment sought to resume the critical role and the role of journalism in problematizing our society. The dimension of gender solidarity was also one of the targets of these actions, so the phrase "respect the girls!", used by different groups in collective actions in defense of women, has been taken up in several publications and comments associated with the campaign.

The striking inter discursivity that we locate in the relations between the Denunciation Discursive Formation and the Confrontation Strategies Discursive Formation, discussed earlier, and the feminist inter discourse echoes what De Lauretis 
(1986) proposes when he affirms that feminism would have brought a new way of thinking not only about culture, but about the experience itself. In this sense, we see the feminist inter discourse present in both Discursive Formations (Denunciation and Confrontation Strategies), pointing out the criticisms of the silencing/omission manifest in Silencing Discursive Formation. This interdiscursivity also reminds us of what Guacira Lopes Louro (1997, p. 159) affirms, stressing that "feminist women and men need to be attentive to the power relations that are part of several social dynamics - of which they take part." And the journalists, but predominantly women journalists, in our study, expressed their concern about the power relations registered in the chronicle environment "'The Intern'/Melissinha's first day of work," to the point of establishing the discursive battle described here.

It is interesting to note that, when publicly active and critical in the networks, these actors contributed to reveal how the chronicle, in this case, operated in the public space as a discourse that reiterates the dominant hierarchical order of genres, discursively reasserting the asymmetrical place proposed to the woman interns in the authority structure of the newspaper. By instituting a discursive battle, the groups disputed in the networks the meaning of the chronicle, denying this proposed asymmetrical place and recognizing the power of language to act on the real by means of eloquent acts (Butler, 2003, p. 169).

\section{Final Considerations}

The publication of the chronicle "'The Intern'/Melissinha's first day of work" in the newspaper Correio Braziliense and the subsequent negative repercussions on the sexist content of the text on the Internet make it possible to understand how the mechanisms of maintenance of gender inequality in journalistic companies act. At the same time, it shows how institutional actors such as class entities, such as Fenaj and Syndicate of Journalists of the Federal District, and collectives of women journalists, such as Journalists against Harassment, played a fundamental role in manifesting themselves through Denunciation Discursive Formation and 
Confrontation Strategies Discursive Formation, directing them as a critical force against the Silencing Discursive Formation undertaken by the newspaper.

The case makes explicit the phenomenon of the feminization of journalism in the country, where the large presence of women in the profession, pointed out by several surveys, has not yet guaranteed effective conditions of equity within the professional field. However, in the present study, feminization has made it possible to undertake discursive battles in the fight against gender discrimination against journalistic female interns or against female journalists. By sexualizing the entrance of young female journalism students into the newspaper's editorial staff, the chronicle's discourse reproduced and naturalized gender violence that is systematically installed in these professional spaces. Such public naturalization initiated a discursive battle in the networks, triggering Discursive Formations of denunciation and organization of confronting strategies by groups and class entities. In this way, the mobilization actions triggered by these groups were able to set in motion the initial silencing of the newspaper, observed through the Silencing Discursive Formation, which led to the later public recognition of the sexist nature of the content of the newspaper chronicled by the editor-in-chief of Correio Braziliense.

Although the repercussion was largely restricted to the area, the reactions had the merit of shifting the debate from the newsroom space to the field of gender inequality discussions, in interdiscursivity with feminist theories and movements. In this sense, the use, for example, of the motto "respect the girls!" in the campaign is symbolic of this discursive battle that we perceive as emblematic of the feminization process of the professional field of journalism in Brazil.

*This paper was translated by Audrey Frischknecht 
1 In Brazil, internship in journalism became mandatory in 2013 with the approval of the new guidelines of the National Education Council.

2 The compulsory journalism degree diploma for the exercise of the profession was in force between 1969, through the DecreeLaw 972/1969, and the year 2009, when the Federal Supreme Court decided to suspend the requirement of the diploma. Currently, bills are being processed in the National Congress with the objective of reestablishing the compulsory diploma for the exercise of journalism in the country.

3 From original: “. . . saisir les pratiques individuelles em les rapportant à leurs conditions sociales et historiques de possibilite et de déroulement, à leur espace du possibilité et du pensable".

4 The authors thank the undergraduate students of the Faculty of Communication, Victoria Franco and Matheus Pontes, for their participation in the data collection phase.

5 About feminist waves, see: Navarro-Swain (2000)

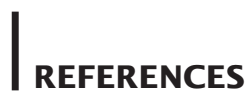

Arruda, A. (2000). Feminismo, gênero e representações sociais. Textos de História: Revista da Pós-Graduação em História da UnB. Brasília, 8(1-2), pp. 113-138.

Associação Nacional de Jornais [ANJ]. (2015). Maiores jornais do Brasil. Retrieved from: www.anj.org.br/maiores-jornais-do-brasil.

Butler, J. (2003). Problemas de gênero: feminismo e subversão da identidade. Rio de Janeiro: Civilização Brasileira.

Buton, F. (2009). Portrait du politiste en socio-historien: La "sociohistoire" dans les sciences politiques. In F. Buton, N. Mariot (dirs.), Pratiques et méthodes de la socio-histoire (pp. 1-22). Paris: PUF.

Byerly, C. M. (Ed). (2011). Global Report on the status of women in the news media. Washington, DC: International Women's Media Foundation. 
Byerly, C. M. (Ed.). (2013). The Palgrave International Handbook of Women and Journalism. New York: Palgrave Macmillan.

Carvalho, G., e Portela, M. R. (2016). Jornalistas intimidadas: Dados da violência moral na Região Sul do Brasil. XVII Congresso de Ciências da Comunicação da Região Sul. Curitiba. Annals.

De Lauretis, T. (1986). Feminist Studies/Critical Studies: Issues, terms, and contexts. In De Lauretis, T. (Ed.), Feminist Studies/Critical Studies (pp. 1-19). Bloomington e Indianapolis: Indiana University Press.

Del Vecchio-Lima, M., \& Souza, H. A. (2017, dezembro). Espaços alternativos na internet como formas de visibilizar as mulheres no jornalismo brasileiro. Media \& Jornalismo, 17(31), pp. 131152. Retrieved from www.scielo.mec.pt/scielo.php?script=sci_ arttext\&pid=S2183-54622017000200010.

Dubeux, A. (2017, setembro 13). Visão do Correio: Hora de mudar. Correio Braziliense, Cidades, p. 10.

Ferreira, M. C. L. (2010). Análise do discurso e suas interfaces. O lugar do sujeito na trama do discurso. Organon. Revista do Instituto de Letras da UFRGS, 24 (48), pp 1-12. Retrieved from http://www.seer.ufrgs.br/index.php/organon/article/ view/28636/17316.

Goulart, G. (2017a, setembro 11). A estagiária/O primeiro dia de trabalho de Melissinha. Correio Braziliense, Cidades, p. 16.

Goulart, G. (2017b, setembro 12). Crônica da Cidade: um erro sem perdão. Correio Braziliense, Cidades. Retrieved from www. correiobraziliense.com.br/app/noticia/cidades/2017/09/12/ interna_cidadesdf,625140/cronica-da-cidade-um-erro-sem-perdao. shtml.

Gudipaty, N., Ramaprasad, J., Pasti, S., Lago, C., Li, X., \& RodnyGumede, Y. (2018). Towards equality? In: S. Pasti, J. Ramaprasad (Eds.), Contemporary Brics Journalism: Non-western media in transition (pp.104-129). Londres: Routledge.

Koshiyama, A.M. Mulheres jornalistas na imprensa brasileira. (2001, September). XXIV Congresso Brasileiro de Ciências da Comunicação, Campo Grande. Annals.

Louro, G. L. (1997). Gênero, sexualidade e educação: Uma perspectiva pós-estruturalista. Petrópolis: Vozes.

Machado, L. M. M. (2017). A Fragilidade dos Laços Femininos: as representações sobre o rompimento da amizade entre duas garotas na série Stranger Things. In C. Stevens, S. Oliveira, V. Zanello. (Eds.), Mulheres e Violências (pp. 114-126), Interseccionalidades. Brasília: Technopolitik. 
Maingueneau, D. (2002). Análise de textos de Comunicação. (2nd ed.). São Paulo: Cortez.

Maingueneau, D. (1997). Novas Tendências em Análise do Discurso. (3rd ed.). Campinas: Editora da Universidade Estadual de Campinas.

Martinez, M., Lago, C., e Lago, M. C. de S. (2016). Estudos de gênero na pesquisa em jornalismo no Brasil: uma tênue relação. Revista Famecos, 23(2), pp. 1-23.

Mick, J., \& Lima, S. P. (2013). Perfil do jornalista brasileiro: características demográficas, políticas e do trabalho jornalístico em 2012. (1 st ed.). Florianópolis: Insular.

Navarro-Swain, T. (Ed.). (2000). Feminismo: teorias e perspectivas. Textos de História: Revista do Programa de Pós-graduação em História da UnB, 8(1-2), pp. 5-8.

Orlandi, E. P. (2003). A análise de Discurso em suas diferentes tradições intelectuais: o Brasil. Seminário de Estudos em Análise de Discurso. Porto Alegre, RS, Brasil, 1. Annals. Retrieved from www. analisedodiscurso.ufrgs.br/anaisdosead/1SEAD/Conferencias/ EniOrlandi.pdf.

Orlandi, E. P. (2007). As Formas do Silêncio: no movimento dos sentidos. (6th ed.). Campinas: Editora da Unicamp.

Pena, F. (2007). Teorias do Jornalismo. (2nd ed.). São Paulo: Contexto.

Ramos, R. H. P. (2010). Mulheres Jornalistas: A grande invasão. São Paulo: Imprensa Oficial/Fundação Cásper Líbero.

Rocha, P. M. (2004). As Mulheres Jornalistas no Estado de São Paulo: O Processo de Profissionalização e Feminização da Carreira. PhD Dissertation. Universidade Federal de São Carlos, Brazil.

Rocha, P. M., Oliveira, M. A., \& Kuhl, C. E. (2013). A história do ingresso das mulheres nas redações de dois impressos de Ponta Grossa. $9^{\circ}$ Encontro Nacional de História da Mídia. Ouro Preto. Annals.

Rocha, P. M., \& Sousa, J. P. (2011). O mercado de trabalho feminino em jornalismo: Análise comparativa entre Portugal e Brasil. Impulso, 21(51), pp. 8-18.

Rocha, P. M., \& Woitowicz, K. J. (2017). O processo de feminização do jornalismo: da invisibilidade às mudanças no mercado profissional. $13^{\circ}$ Women's Worlds / $11^{\circ}$ Fazendo Gênero. Tranformations, connections, displacements. Florianópolis. Annals.

Silva, M. V. (2014). Masculino, o gênero do jornalismo: Modos de produção das notícias. Florianópolis: Insular. 
Sindicato dos Jornalistas Profissionais do Distrito Federal [SJPDF]. (2016). Pesquisa Desigualdade de Gênero no Jornalismo. Brasília: SJPDF. Retrieved from www.sjpdf.org.br/images/Pesquisa Desigualdade_de_G\%C3\%AAnero_no_Jornalismo_-_Resultados.pdf

Souza, A. F. C. (2009). Mulheres jornalistas: percursos e percalços. $V$ Encontro de Estudos Multidisciplinares em Cultura/ ENECULT, Salvador. Anais. Retrieved from www.cult.ufba.br/ enecult2009/19152.pdf.

Souza, E. M., \& Bueno, J. M. (2017). Elas na TV: de piadas a gracejos: um estudo sobre o assédio na perspectiva de jornalistas e estudantes de jornalismo de Uberlândia/MG. V Seminário Catarinense sobre Prevenção ao Assédio Moral no Trabalho. Florianópolis. Annals. Retrieved from neppot.ufsc.br/files/2017/11/2017-Anais-do-evento. pdf\#page=41.

Yannoulas, S. (2011). Feminização ou femilização: Apontamentos em torno de uma categoria. Temporalis, 11(22), pp. 271-292.

Liziane Guazina. PhD, Adjunct Professor at the Faculty of Communication/University of Brasília (UnB), Brasília, Federal District, Brazil. E-mail: liziane.g@uol.com.br

Conception, design, intellectual and scientific content of the study; manuscript writing and final edition.

Dione Oliveira Moura. PhD, Associate Professor at the Faculty of Communication/University of Brasília (UnB), Brasília, Federal District, Brazil. E-mail: dioneoliveiramoura@gmail.com

Conception, design, intellectual and scientific content of the study; manuscript writing and final edition.

Fabíola Calazans. PhD, Adjunct professor at the Faculty of Communication/University of Brasília (UnB), Brasília,Federal District, Brazil. E-mail: fabiola.calazans@gmail.com 
Design, intellectual and scientific content of the study; acquisition and interpretation of data; manuscript writing and final edition.

Fernanda Martinelli. PhD, Adjunct Professor at the Faculty of Communication/University of Brasília (UnB), Brasília, Federal District, Brazil. E-mail: nandamartineli@yahoo.com.br Design, intellectual and scientific content of the study; acquisition and interpretation of data; manuscript writing and critical revision.

Liliane Machado. PhD, Adjunct Professor at the Faculty of Communication/ University of Brasília (UnB), Brasília, Federal District, Brazil. E-mail: profliliane@globo.com

Design, intellectual and scientific content of the study; acquisition and interpretation of data; manuscript writing and critical revision. 